\title{
Grafting between species of the genus Handroanthus for the production of multi-colored flower canopies
}

\section{Enxertia entre espécies do gênero Handroanthus na produção de copas multicoloridas}

Ingridh Medeiros Simões ${ }^{1}$ (D), José Carlos Lopes² (D), Edilson Romais Schmildt ${ }^{3}$ (D) Adésio Ferreira $^{2}$ (D), Julcinara Oliveira Baptista ${ }^{\text {(D) }}$, Caroline Palacio de Araujo ${ }^{1}$ (D), Thuanny Lins Monteiro Rosa ${ }^{1}$ (1), Genilda Canuto Amaral ${ }^{1}$ (D), Rodrigo Sobreira Alexandre ${ }^{1}$ (1)

${ }^{1}$ Universidade Federal do Espírito Santo - UFES, Jerônimo Monteiro, ES, Brasil

Universidade Federal do Espírito Santo - UFES, Alegre, ES, Brasil

${ }^{3}$ Universidade Federal do Espírito Santo - UFES, São Mateus, ES, Brasil

How to cite: Simões, I. M., Lopes, J. C., Schmildt, E. R., Ferreira, A., Baptista, J. O., Araujo, C. P., Rosa, T. L. M., Amaral, G. C., \& Alexandre, R. S. (2021). Grafting between species of the genus Handroanthus in the production of multi-colored canopies. Scientia Forestalis, 49(132), e3701. https://doi.org/10.18671/scifor.v49n132.07

\begin{abstract}
Urban afforestation is done with trees with adequate size for streets, squares and avenues, as well as those with showy canopies. Trees of the genus Handroanthus and belonging to the family Bignoniaceae are widely used due to their canopies flowering in different colors used for landscape purposes. The use of techniques such as grafting, which assist in early flowering and the possibility of canopies producing flowers of different colors can be of importance. This study aimed to analyze the grafting compatibility in bifurcated seedlings of the genus Handroanthus for the production of multi-colored flowering canopies. The experiment was constituted by 10 treatments, with different scion/rootstock combinations. The studied species were Handroanthus heptaphyllus ( $\mathrm{Hh})$, Handroanthus impetiginosus $(\mathrm{Hi})$, Handroanthus chrysotrichus $(\mathrm{Hc})$, and Handronthus roseo-albus ( $\mathrm{Hr}$-a), using $\mathrm{Hi}$ as the only rootstock species (via seeds), and the remaining species, including $\mathrm{Hi}$ from adult plants as scions. Single-stem wedge grafting on a bifurcated seedling was adopted for the following combinations: 1. $\mathrm{Hc} / \mathrm{Hi} ; 2$. $\mathrm{Hr}-\mathrm{a} / \mathrm{Hi} ; 3$. $\mathrm{Hh} / \mathrm{Hi} ; 4$. $\mathrm{Hi} / \mathrm{Hi}$, whereas double-stem wedge grafting was adopted for: 5. $\mathrm{Hi} / \mathrm{Hi}$ and $\mathrm{Hc} / \mathrm{Hi}$; 6. $\mathrm{Hi} / \mathrm{Hi}$ and $\mathrm{Hr}-\mathrm{a} / \mathrm{Hi}$; 7. $\mathrm{Hi} / \mathrm{Hi}$ and $\mathrm{Hh} / \mathrm{Hi} ; 8 . \mathrm{Hc} / \mathrm{Hi}$ and $\mathrm{Hr}-\mathrm{a} / \mathrm{Hi} ; 9$. $\mathrm{Hc} / \mathrm{Hi}$ and $\mathrm{Hh} / \mathrm{Hi}$; and $10 . \mathrm{Hr}-\mathrm{a} / \mathrm{Hi}$ and $\mathrm{Hh} / \mathrm{Hi}$ ), with three replications of five seedlings. The take percentage and vigor were evaluated 50 days after grafting. The highest establishment rates for the single-stem wedge grafting were obtained by the same species grafts $\mathrm{Hi} / \mathrm{Hi}(80 \%)$ and by the $\mathrm{Hr}-\mathrm{a} / \mathrm{Hi}(86.6 \%)$ combination; whereas for the double-stem grafting the following percentages of combinations were obtained: $\mathrm{Hc} / \mathrm{Hi}$ (93.3\%) and $\mathrm{Hr}-\mathrm{a} / \mathrm{Hi}$ (93.3\%); $\mathrm{Hc} / \mathrm{Hi}$ (73.3\%) and $\mathrm{Hh} / \mathrm{Hi}$ (86.6\%); and $\mathrm{Hr}-\mathrm{a} / \mathrm{Hi}$ (86.6\%) and $\mathrm{Hh} / \mathrm{Hi}(86.6 \%)$.
\end{abstract}

Keywords: Handroanthus spp.; Ipe trees; Vegetative propagation; Wedge grafting; Colorful canopies.

\section{Resumo}

A arborização urbana utiliza árvores com tamanho adequado para ruas, praças e avenidas, bem como aquelas com copas vistosas. Árvores do gênero Handroanthus e pertencentes à família Bignoniaceae são amplamente utilizadas devido às suas copas com cores variadas, muito utilizadas para fins paisagísticos. A utilização de técnicas, como a enxertia, que auxiliam no florescimento precoce e a possibilidade de copas policoloridas são de extrema importância. Objetivou-se com esse trabalho analisar a compatibilidade de enxertia em mudas bifurcadas do gênero Handroanthus, na produção de copas policoloridas. O experimento foi constituído por 10 tratamentos, com diferentes combinações de enxerto/porta-enxerto. As espécies estudadas foram Handroanthus heptaphyllus (Hh), Handroanthus impetiginosus (Hi), Handroanthus chrysotrichus $(\mathrm{Hc})$ e Handronthus roseo-albus ( $\mathrm{Hr}$-a), usando Hi como única espécie de porta-enxerto (via sementes), e as espécies restantes, incluindo $\mathrm{Hi}$, como enxerto (de plantas adultas). Adotou-se a garfagem no topo em fenda cheia

Financial support: Nothing to declare.

Conflict of interest: Nothing to declare.

Corresponding author: simoes.ingridh@gmail.com

Received: 18 April 2021.

Accepted: 6 May 2021

Editor: Paulo Henrique Müller Silva. (c) This is an Open Access article distributed under the terms of the Creative Commons Attribution License, which permits unrestricted use,
distribution, and reproduction in any medium, provided the original work is properly cited. 
sobre muda bifurcada para as seguintes combinações: 1. Hc/Hi; 2. $\mathrm{Hr}-\mathrm{a} / \mathrm{Hi}$; 3. $\mathrm{Hh} / \mathrm{Hi}$; 4. Hi/Hi, enquanto o enxerto em cunha de haste dupla foi adotado para: 5. $\mathrm{Hi} / \mathrm{Hi}$ e Hc/Hi; 6. $\mathrm{Hi} / \mathrm{Hi}$ e $\mathrm{Hr}-\mathrm{a} / \mathrm{Hi} ; 7$. $\mathrm{Hi} / \mathrm{Hi}$ e Hh/Hi; 8. $\mathrm{Hc} / \mathrm{Hi}$ e $\mathrm{Hr}-\mathrm{a} / \mathrm{Hi} ; 9$. $\mathrm{Hc} / \mathrm{Hi}$ e $\mathrm{Hh} / \mathrm{Hi}$; e 10. $\mathrm{Hr}$-a/Hi e $\mathrm{Hh} / \mathrm{Hi}$ ), com três repetições de cinco mudas. A porcentagem de pegamento e o vigor foram avaliados após 50 dias da montagem do experimento. As maiores taxas de pegamento para a enxertia de haste única foram obtidas pela autoenxertia $\mathrm{Hi} / \mathrm{Hi}(80 \%)$ e pela combinação $\mathrm{Hr}$ - a/Hi (86,6\%), enquanto para a enxertia de haste dupla foram obtidas por combinações $\mathrm{Hc} / \mathrm{Hi}(93,3 \%)$ e $\mathrm{Hr}-\mathrm{a} / \mathrm{Hi}(93,3 \%) ; \mathrm{Hc} / \mathrm{Hi}(73,3 \%)$ e Hh/Hi (86,6\%); e Hr-a/Hi (86,6\%) e Hh/Hi (86,6\%).

Palavras-chave: Handroanthus spp.; Ipê; Propagação vegetativa; Garfagem em fenda cheia; Copa colorida.

\section{INTRODUCTION}

Urban afforestation aims to improve the quality of life of citizens and mitigate some environmental effects such as high temperatures and air pollution (Van Ryswyk et al., 2019; Storch-Böhm et al., 2020). Trees of the Bignoniaceae family belonging to the Handroanthus genus are commonly used on urban roads, as they have crowns with colorful inflorescences and are suitable for streets, squares and avenues (Backes et al., 2011).

Flower coloring in trees of the genus Handroanthus can feature the following colors: purple (Handroanthus heptaphyllus (Mart.) Mattos), pink (Handroanthus impetiginosus (Mart. ex DC.) Mattos), yellow (Handroanthus chrysotrichus (Mart. ex DC.) Mattos), or white (Handronthus roseo- albus (Ridl.) Mattos). A mixture of colors can be observed in inflorescences of the hybrid Handroanthus $\times$ lewisii, whose flowers exhibit details in yellow and magenta (Hodel et al., 2017).

In view of the beauty of these trees the following question emerges: is it possible to produce a single individual with flowers of multiple colors in canopies through vegetative propagation by the use of the grafting technique? This technique proved useful for the propagation of $H$. heptaphyllus and $H$. impetiginosus, in which it was observed that the clones were able to keep their early flowering habits and flower quality (Facciuto et al., 2005).

Grafting is a technique that permits the rapid transition from the vegetative to the reproductive stage, being widely used when trying to obtain the adaptation of plants to acid and saline soils or to the attack by diseases caused by nematodes, fungi, and bacteria, increasing production through the use of adapted rootstocks and high-yielding scions (Orazem et al., 2011; Font i Forcada et al., 2012; Hussain et al., 2013).

This study aimed to analyze the grafting compatibility in bifurcated seedlings of the genus Handroanthus for the production of multi-colored canopies.

\section{MATERIAL AND METHODS}

In order to perform this study, seedlings of $H$. impetiginosa (pink trumpet tree) were used as rootstocks, with its seeds being sown in a sandy substrate sterilized at a temperature of $100{ }^{\circ} \mathrm{C}$ for 48 hours. Sowing was performed in plastic trays, which were kept in germination chambers at a temperature of $25^{\circ} \mathrm{C}$ and a photoperiod of 8 hours.

After the emergence, the pink trumpet tree seedlings with five centimeters of height were transported to a forest plant nursery and transplanted with naked roots to seedling pots with a volume of $3,780 \mathrm{~cm}^{3}$, containing in their interior the commercial substrate Bioplant $\AA$.

The rootstocks produced from seeds, after attaining approximately $20 \mathrm{~cm}$ height and $7 \mathrm{~mm}$ base diameter, where subjected to apical dormancy breaking aiming at the production of bifurcated seedlings. The grafting method employed in either one or both sprouts was by top wedge-grafting with a cut of approximately $1 \mathrm{~cm}$ length.

The scions were collected from adult plants of the genus Handroantus with approximately $7 \mathrm{~cm}$ length and were subjected to a double bevel cut at the base. Afterward, the union of scion and rootstock was performed by inserting the wedge in the cut of the rootstock, so that the bark of rootstocks and scions coincided in at least one of the sides.

The grafting region was wrapped with tire tube strips, which exerted pressure onto scion and rootstock. In sequence a wet chamber aiming at avoiding tissue dehydration was produced by covering the region with a plastic bag, which was wrapped as a cylinder and closed with a string at its lower end. 
The experimental design was in randomized blocks, with 10 treatments and three replications per treatment, with five plants each. The treatments consisted of the scion/rootstock combinations in each of the plants, using the species: Handroanthus heptaphyllus (purple trumped tree, Hh); Handroanthus impetiginosus (pink trumpet tree, Hi); Handroanthus chrysotrichus (yellow trumpet tree, $\mathrm{Hc}$ ), and Handroanthus roseo-albus (white trumped tree, Hra). One graft was done on one stem of the bifurcated seedlings with the following combinations: (T1. Hc/Hi; T2. Hr-a/Hi; T3. Hh/Hi; T4. Hi/Hi); while two grafts were done on the two stems of the bifurcated seedlings as follows: (T5. $\mathrm{Hc} / \mathrm{Hi}$ and $\mathrm{Hi} / \mathrm{Hi}$; T6. $\mathrm{Hr}-\mathrm{a} / \mathrm{Hi}$ and $\mathrm{Hi} / \mathrm{Hi}$; T7. $\mathrm{Hh} / \mathrm{Hi}$ and $\mathrm{Hi} / \mathrm{Hi}$; T8. $\mathrm{Hc} / \mathrm{Hi}$ and $\mathrm{Hr}-\mathrm{a} / \mathrm{Hi} ; \mathrm{T}$. $\mathrm{Hc} / \mathrm{Hi}$ and $\mathrm{Hh} / \mathrm{Hi} ; \mathrm{T} 10 . \mathrm{Hr}-\mathrm{a} / \mathrm{Hi}$ and $\mathrm{Hh} / \mathrm{Hi}$ ) (Figure 1).

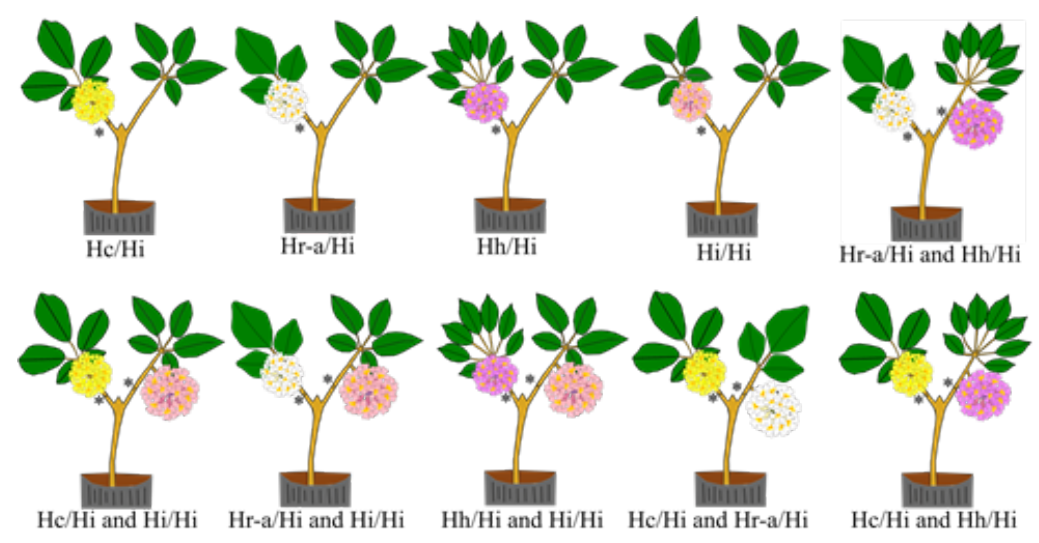

Figure 1. Scheme evidencing the grafting treatments performed in seedlings of $H$. impetiginosus (Hi) used as rootstocks and combinations of scions of different species of the genus Handroanthus. *=graft union.

Fifty days after grafting data were taken of: survival (\%); number of shoots per graft; shoot growth increment $(\mathrm{cm})$; scion diameter increment $(\mathrm{mm})$; rootstock diameter increment $(\mathrm{mm})$; graft region diameter increment $(\mathrm{mm})$.

The data were subjected to analysis of variance and Scott-Knott test of means $(p<0.05)$. The homoscedasticity test was carried out according to O'Neill \& Mathews (2000). All analyses were performed using the R software (R Core Team, 2021) using the "ExpDes.pt" package (Ferreira et al., 2018).

\section{RESULTS AND DISCUSSION}

According to the O'Neill \& Mathews (2000) test at 5\% significance, the variances can be considered homogeneous. By the Shapiro-Wilk test at 5\% significance, the residues are normal.

The present work is a continuation of Simões et al. (2021), aiming to analyze the formation of crowns with flowers of different colors. And yet, this work needed the results of the first one for its execution.

In the same species grafting of Hi the take (80\%) and the increments in scion, rootstock, and graft region diameter yielded the best results, confirming the intraspecific compatibility in the single-stem grafting (Table 1 and 2). Facciuto et al. (2005) in the $\mathrm{Hh} / \mathrm{Hh}$ and $\mathrm{Hh} / \mathrm{Hi}$ combinations found a mean wedge grafting take of $91.7 \%$. Same species grafting through the wedge method is efficient for favoring fast healing, growth, and survival of the graft (Opoku et al., 2019; Simões et al. 2021).

The single-stem establishment was also superior in the $\mathrm{Hr}$-a/Hi combination (86.6\%) (Table 2). The compatibility between scion and rootstock is observed through some characteristics such as callus formation in the union, which is an indicator of tissue healing, as well as the long-term survival (Mudge et al., 2009), the connection between xylem and phloem vessels (Johkan et al., 2009). In addition, other factors can influence the take, such as the origin of the scions (Robert et al., 2019), and the type of genetic material used as a scion (Baron et al., 2019) (Figure 2). 


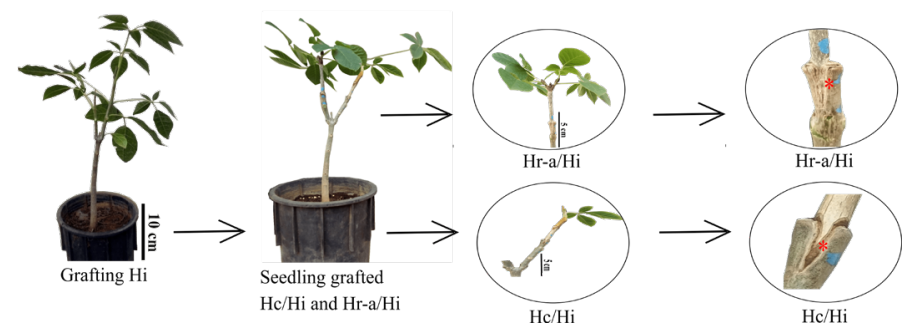

Figure 2. Schematic showing the attachment between the scion and rootstock of a bifurcated seedling for the $\mathrm{Hc} / \mathrm{Hi}$ and $\mathrm{Hr}-\mathrm{a} / \mathrm{Hi}$. *= graft union with callus.

It is necessary to monitor the grafting process in the nursery and even years afterwards, as there are cases of late rejection in the field that can cause later problems. According to Ferrari et al. (2004) rejection can occur immediately after grafting or even years after the process. In the grafting of Cedrela fissilis (white cedar) on Toona ciliata var. australis (australian cedar) the take was over $90 \%$ in the nursery and two years after planting in the field, there was a swelling at the base of the plant ("elephant feet"), which is an indication of late rejection (Kalil Filho et al., 2008).

The cortex and phloem tissues act in the regeneration and connection of the graft. Woody species that contain more cortex and phloem in the rootstock or canopy present a greater grafting success potential (Balbi et al., 2019). The high vigor of the European pear cultivars Abbè Fetel and Rocha was attributed to several probable factors, such as the EMC rootstock (East Malling " $\mathrm{C}^{\prime \prime}$ ), which resulted in a lower deposition of succinic acid, due to the continuous flow in the grafted region and the high connectivity between the xylems of the canopy cultivars (Machado et al., 2017). The regulation of the graft union process can occur via the calcium and MAPK signaling pathways (mitogen-activated protein kinases), which occur during the development of the vascular cylinder and by cell proliferation and differentiation (Feng et al., 2017).

Another relevant factor for the obtainment of high take rates is the morphological and physiological affinity of the plants, where the junction of morphological and anatomical characteristics favors the union of tissues by the better adjustment between rootstock and scion, since the physiological affinity relates to the composition of the sap, providing efficiency in the healing process (Peil, 2003).

Table 1. ANOVA for each variable under study.

\begin{tabular}{|c|c|c|c|c|c|c|c|c|c|c|c|}
\hline \multicolumn{6}{|c|}{ Establishment (E) } & \multicolumn{6}{|c|}{ Scion diameter increment (SDI) } \\
\hline $\mathbf{S}$ & DF & SS & MS & $\mathbf{F}$ & P-value & $\mathbf{S}$ & DF & SS & MS & $\mathbf{F}$ & P-value \\
\hline $\operatorname{Tr}$ & $15^{1}$ & 6125 & 408.3 & 3.551 & $0.00152 *$ & $\operatorname{Tr}$ & 15 & 50.396 & 3.3597 & 11.882 & $0.00000 *$ \\
\hline$B$ & 2 & 816.7 & 408.3 & 3.551 & $0.04130 *$ & B & 2 & 3.385 & 1.6925 & 3.551 & $0.00649 *$ \\
\hline$E$ & 30 & 3450 & 115.0 & & & $E$ & 30 & 8.483 & 0.2828 & & \\
\hline $\mathrm{T}$ & 47 & 10392 & 221.1 & & & $\mathrm{~T}$ & 47 & 62.265 & 1.3248 & & \\
\hline \multicolumn{6}{|c|}{ Number of shoots per graft (NS) } & \multicolumn{6}{|c|}{ Rootstock diameter increment (RDI) } \\
\hline $\mathbf{S}$ & DF & SS & MS & $\mathbf{F}$ & P-value & $\mathbf{S}$ & DF & SS & MS & $\mathbf{F}$ & P-value \\
\hline $\operatorname{Tr}$ & 15 & 3.1156 & 0.2070 & 2.512 & $0.01544 *$ & $\operatorname{Tr}$ & 15 & 9.0132 & 0.6009 & 2.760 & $0.00872 *$ \\
\hline $\mathrm{B}$ & 2 & 0.3801 & 0.1900 & 2.299 & $0.11780 *$ & B & 2 & 0.2424 & 0.1212 & 3.551 & $0.57888 *$ \\
\hline $\mathrm{E}$ & 30 & 2.4801 & 0.0827 & & & $\mathrm{E}$ & 30 & 6.531 & 0.2177 & & \\
\hline $\mathrm{T}$ & 47 & 5.9758 & 0.1271 & & & $\mathrm{~T}$ & 47 & 15.787 & 0.3359 & & \\
\hline \multicolumn{6}{|c|}{ Shoot growth increment (SGI) } & \multicolumn{6}{|c|}{ Graft region diameter increment (GRDI) } \\
\hline $\mathbf{S}$ & DF & SS & MS & $\mathbf{F}$ & P-value & $\mathbf{S}$ & DF & SS & MS & $\mathbf{F}$ & P-value \\
\hline $\operatorname{Tr}$ & 15 & 21.576 & 1.4384 & 1.944 & $0.05911 *$ & $\operatorname{Tr}$ & 15 & 39.284 & 2.6189 & 4.797 & $0.00013^{*}$ \\
\hline $\mathrm{B}$ & 2 & 2.715 & 1.3575 & 1.835 & $0.17704 *$ & B & 2 & 0.102 & 0.051 & 3.551 & $0.91137 *$ \\
\hline$E$ & 30 & 22.193 & 0.7398 & & & $E$ & 30 & 16.38 & 0.546 & & \\
\hline $\mathrm{T}$ & 47 & 46.484 & 0.9890 & & & $\mathrm{~T}$ & 47 & 55.766 & 1.1865 & & \\
\hline
\end{tabular}

1 *Significant by the F test ( $>0.05)$. Caption: S. Source; Tr. Treatments; B. Block; E. Error; T. Total; DF. Degrees of freedom; SS. Sum of squares; MS. Mean square; F. Statistical test; P-value. Statistical value. 
Table 2. Characteristics evaluated in the grafting between combinations of scions and rootstocks of Handroanthus species.

\begin{tabular}{|c|c|c|c|c|c|c|c|c|}
\hline \multirow[b]{2}{*}{ NGS } & \multirow[b]{2}{*}{ Treatments } & \multirow{2}{*}{$\begin{array}{l}\text { Scion/rootstock } \\
\text { combinations }\end{array}$} & \multicolumn{6}{|c|}{ Features } \\
\hline & & & $E(\%)$ & NS & SGI (cm) & SDI (mm) & $\begin{array}{l}\text { RDI } \\
(\mathrm{mm})\end{array}$ & $\begin{array}{l}\text { GRDI } \\
(\mathrm{mm})\end{array}$ \\
\hline \multirow{4}{*}{$\stackrel{0}{\complement}$} & T1 & $\mathrm{Hi} / \mathrm{Hi}$ & $80.0 a^{1}$ & $1.0 \mathrm{~b}$ & $2.8 \mathrm{a}$ & $6.9 a$ & $6.0 \mathrm{a}$ & $7.9 \mathrm{a}$ \\
\hline & T2 & $\mathrm{Hr}-\mathrm{a} / \mathrm{Hi}$ & $86.6 \mathrm{a}$ & $1.6 \mathrm{a}$ & $2.4 \mathrm{a}$ & $4.8 \mathrm{~b}$ & $5.8 \mathrm{a}$ & $7.0 \mathrm{~b}$ \\
\hline & T3 & $\mathrm{Hc} / \mathrm{Hi}$ & $73.3 b$ & $1.5 \mathrm{a}$ & $1.9 \mathrm{a}$ & $4.7 \mathrm{~b}$ & $6.0 \mathrm{a}$ & $6.8 \mathrm{~b}$ \\
\hline & $\mathrm{T} 4$ & $\mathrm{Hh} / \mathrm{Hi}$ & 66.6 b & $1.6 \mathrm{a}$ & $1.3 \mathrm{a}$ & $5.3 \mathrm{~b}$ & $5.5 a$ & $6.8 \mathrm{~b}$ \\
\hline \multirow{16}{*}{ 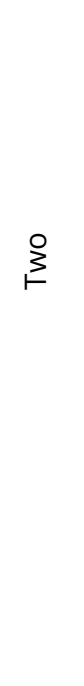 } & \multirow{2}{*}{ T5 } & $\mathrm{Hi} / \mathrm{Hi}$ & $80.0 \mathrm{a}$ & $1.0 \mathrm{~b}$ & $3.1 \mathrm{a}$ & $6.2 \mathrm{a}$ & $6.0 \mathrm{a}$ & $7.8 a$ \\
\hline & & $\mathrm{Hc} / \mathrm{Hi}$ & $60.0 \mathrm{~b}$ & $1.0 \mathrm{~b}$ & $3.7 \mathrm{a}$ & $4.2 \mathrm{~b}$ & $5.5 \mathrm{a}$ & $5.5 c$ \\
\hline & \multirow{2}{*}{ T6 } & $\mathrm{Hi} / \mathrm{Hi}$ & $60.0 \mathrm{~b}$ & $1.0 \mathrm{~b}$ & $2.2 \mathrm{a}$ & $6.7 a$ & $6.2 \mathrm{a}$ & $8.2 \mathrm{a}$ \\
\hline & & $\mathrm{Hr}-\mathrm{a} / \mathrm{Hi}$ & $60.0 \mathrm{~b}$ & $1.3 \mathrm{a}$ & $1.7 \mathrm{a}$ & $4.4 \mathrm{~b}$ & $5.2 \mathrm{a}$ & $5.7 \mathrm{c}$ \\
\hline & \multirow{2}{*}{ T7 } & $\mathrm{Hi} / \mathrm{Hi}$ & $80.0 \mathrm{a}$ & $1.0 \mathrm{~b}$ & $2.5 \mathrm{a}$ & $7.5 \mathrm{a}$ & $6.0 \mathrm{a}$ & $8.1 \mathrm{a}$ \\
\hline & & $\mathrm{Hh} / \mathrm{Hi}$ & $66.6 \mathrm{~b}$ & $1.4 \mathrm{a}$ & $1.6 \mathrm{a}$ & $4.6 \mathrm{~b}$ & $5.5 \mathrm{a}$ & $5.8 \mathrm{c}$ \\
\hline & \multirow{2}{*}{ T8 } & $\mathrm{Hc} / \mathrm{Hi}$ & $93.3 \mathrm{a}$ & $1.0 \mathrm{~b}$ & $2.6 \mathrm{a}$ & $4.0 \mathrm{~b}$ & $5.1 \mathrm{a}$ & $6.0 \mathrm{c}$ \\
\hline & & $\mathrm{Hr}-\mathrm{a} / \mathrm{Hi}$ & $93.3 \mathrm{a}$ & $1.6 \mathrm{a}$ & $2.5 \mathrm{a}$ & $4.8 \mathrm{~b}$ & $5.4 \mathrm{a}$ & $6.8 \mathrm{~b}$ \\
\hline & \multirow{2}{*}{ T9 } & $\mathrm{Hc} / \mathrm{Hi}$ & $73.3 \mathrm{~b}$ & $1.3 \mathrm{a}$ & $2.0 \mathrm{a}$ & $4.6 \mathrm{~b}$ & $5.5 \mathrm{a}$ & $5.6 \mathrm{c}$ \\
\hline & & $\mathrm{Hh} / \mathrm{Hi}$ & $86.6 \mathrm{a}$ & $1.0 \mathrm{~b}$ & $2.1 \mathrm{a}$ & $4.9 \mathrm{~b}$ & $5.5 \mathrm{a}$ & $6.5 \mathrm{~b}$ \\
\hline & \multirow{2}{*}{ T10 } & $\mathrm{Hr}-\mathrm{a} / \mathrm{Hi}$ & $86.6 \mathrm{a}$ & $1.3 \mathrm{a}$ & $1.2 \mathrm{a}$ & $4.2 \mathrm{~b}$ & $4.4 \mathrm{a}$ & $5.7 \mathrm{c}$ \\
\hline & & $\mathrm{Hh} / \mathrm{Hi}$ & $86.6 \mathrm{a}$ & $1.3 \mathrm{a}$ & $1.6 \mathrm{a}$ & $4.7 \mathrm{~b}$ & $5.4 \mathrm{a}$ & $6.6 \mathrm{~b}$ \\
\hline & \multicolumn{2}{|c|}{ Minimum } & 60.0 & 1.0 & 1.2 & 4.0 & 4.4 & 5.5 \\
\hline & \multicolumn{2}{|c|}{ Mean } & 77.1 & 1.2 & 2.2 & 5.2 & 5.6 & 6.7 \\
\hline & \multicolumn{2}{|c|}{ Maximum } & 93.3 & 1.6 & 3.7 & 7.5 & 6.2 & 8.2 \\
\hline & \multicolumn{2}{|c|}{ CV (\%) } & 13.9 & 22.7 & 37.1 & 10.2 & 8.3 & 11.0 \\
\hline
\end{tabular}

${ }^{1}$ Means followed by the same letter in the column, between the combinations of scions $x$ rootstocks, belong to the same cluster by the Scott-Knott test $(p<0.05)$. Legend: NSG. Number of stems grafted in the bifurcated seedling; E. Establishment; NS. Number of shoots per graft; SGI. Shoot growth increment; SDI. Scion diameter increment; RDI. Rootstock diameter increment; GRDI. Graft region diameter increment. Treatments: wedging in one stem of the bifurcated seedling ( $\mathrm{T} 1$. $\mathrm{Hc} / \mathrm{Hi}$; T2. $\mathrm{Hr}-\mathrm{a} / \mathrm{Hi} ; \mathrm{T} 2$. $\mathrm{Hh} / \mathrm{Hi} ; \mathrm{T} 3 . \mathrm{Hi} / \mathrm{Hi}$ ) and wedging in the two stems of the bifurcated seedling (T5. $\mathrm{Hc} / \mathrm{Hi}$ and $\mathrm{Hi} / \mathrm{Hi} ; \mathrm{T} 6 . \mathrm{Hr}-\mathrm{a} / \mathrm{Hi}$ and $\mathrm{Hi} / \mathrm{Hi} ; \mathrm{T} 7$. $\mathrm{Hh} / \mathrm{Hi}$ and $\mathrm{Hi} / \mathrm{Hi} ; \mathrm{T} 8 . \mathrm{Hc} / \mathrm{Hi}$ and $\mathrm{Hr}-\mathrm{a} / \mathrm{Hi} ; \mathrm{T} 9$. $\mathrm{Hc} / \mathrm{Hi}$ and $\mathrm{Hh} / \mathrm{Hi} ; \mathrm{T} 10$. $\mathrm{Hr}-\mathrm{a} / \mathrm{Hi}$ and $\mathrm{Hh} / \mathrm{Hi}$.

In some of the other combinations the take percentage values for single-stem grafting were lower, such as in $\mathrm{Hc} / \mathrm{Hi} \mathrm{(73.3 \% )}$ and $\mathrm{Hh} / \mathrm{Hi}$ (66.6\%) (Table 2). Interspecific grafting tends to lead to lower success rates. Opoku et al. (2019) studying wedge graft between Khaya ivorensis $\mathrm{x}$ Khaya grandifoliola did not obtain high take values, in agreement with the data of the present study. The graft union is successful when there is an exchange of metabolites between the scion and the rootstock; when it is deficient it can negatively influence the taking (Barbosa Filho et al., 2016).

Graft incompatibility is mainly the result of anatomical, physiological, and biochemical differences that lead to the abnormal development of the graft, being able to cause a reduction in growth, resistance to biotic and abiotic factors, low yield, and death of the plant (Martínez-Ballesta et al., 2010; Darikova et al., 2011; Pereira et al., 2014).

Furthermore, molecular changes may occur through the existence of communication and transference of genetic elements from the rootstock to the scion, and vice-versa. In turn, the accumulation and maintenance of epigenetic changes in functional genes and promoters during subsequent cycles of vegetative propagation can contribute to the intra-clonal variability of the graft, as observed in Hevea brasiliensis, leading to the alteration of phenotypes (Uthup et al., 2018).

There are limiting factors to grafting success, such as tissue lignification, (Malagi et al., 2012) as well as beneficial ones, such as auxins (Kumar et al., 2018). For Chinese hickory (Carya cathayensis L.), the PIN, ABCB, and AUX/LAX genes were identified, known for codifying inflow and efflux carriers in the polar transportation of auxin. The increase in the expression of several of such genes, such as CCPIN1 b and CCLAX3, is correlated with the success of grafts (Kumar et al., 2018). 
In the two stem grafts, the canopy/rootstock combinations which showed better take were the $\mathrm{Hc} / \mathrm{Hi}(93.3 \%)$ and $\mathrm{Hr}-\mathrm{a} / \mathrm{Hi}$ (93.3\%) treatments, which in the future, after planting in a permanent location, should lead to the production of a canopy with both colors of flowers due to the growth of the plants; $\mathrm{Hc} / \mathrm{Hi}(73.3 \%)$ and $\mathrm{Hh} / \mathrm{Hi} \mathrm{(86.6 \% ),} \mathrm{canopy} \mathrm{with} \mathrm{yellow} \mathrm{and} \mathrm{purple}$ flowers, and $\mathrm{Hr}-\mathrm{a} / \mathrm{Hi}(86.6 \%)$ and $\mathrm{Hh} / \mathrm{Hi}$ (86.6\%), canopy with white and purple flowers (Table 2). It is emphasized that the production of these colorful canopies does not constitute chimeric hybrids produced through grafting. Such a phenomenon was observed in Laburnocytisus 'Adamii', in which from the graft union of Chamaecytisus purpureus and Laburnum anagyroides an adventitious shoot sprouted with intermediate leaf and flower characteristics between the phenotypic ranges of the grafted organisms (Cowles \& Chamberlain, 1911).

The scion diameter presented the highest values of take in the same species grafting combinations $\mathrm{Hi} / \mathrm{Hi}$. The lowest values were verified in the $\mathrm{Hr}-\mathrm{a} / \mathrm{Hi}$ (mean of 4.5), $\mathrm{Hc} / \mathrm{Hi}$ (mean of 4.3), and $\mathrm{Hh} / \mathrm{Hi}$ combinations (mean of 4.8 ) presenting a value of $4.0 \mathrm{~mm}$ (Table 2). A probable explanation for the success of intraspecific compatibility is the larger diameters of the scion, since generally the diameter of the scion region is slightly larger than the diameter of the rootstock. If there is much difference between the diameter between scion and rootstock, incompatibility of grafting may occur (Rodrigues et al., 2004; Darikova et al., 2011). In addition, the perfect union of the grafts and the larger diameters of the seedlings can favor cell differentiation and callus formation (Gomes et al., 2010).

\section{CONCLUSIONS}

There was compatibility between all wedge grafting combinations in the single-stem and double-stem bifurcated seedlings.

The highest compatibility rates observed for single-stem grafting belonged to the $\mathrm{Hi} / \mathrm{Hi}$ same species grafting (80\%) and in the $\mathrm{Hr}$-a/Hi combination (86.6\%). As for the double-stem grafting, the highest values were registered for the following combinations: $\mathrm{Hc} / \mathrm{Hi}(93.3 \%)$ and $\mathrm{Hr}-\mathrm{a} / \mathrm{Hi}(93.3 \%) ; \mathrm{Hc} / \mathrm{Hi}(73.3 \%)$ and $\mathrm{Hh} / \mathrm{Hi}(86.6 \%) ; \mathrm{Hr}-\mathrm{a} / \mathrm{Hi}(86.6 \%)$ and $\mathrm{Hh} / \mathrm{Hi}(86.6 \%)$.

\section{ACKNOWLEDGMENTS}

To the National Council for Scientific and Technological Development (CNPq) and the Coordination for the Improvement of Higher Education Personnel (CAPES), for the concession of the scholarships and research funding.

\section{REFERENCES}

Backes, F. A. A. L., Girardi, L. B., Neuhaus, M., Bellé, R. A., Schwab, N. T., \& Peiter, M. X. (2011). Caracterização das espécies utilizadas na arborização urbana em Silveira Martins, RS. Ornamental Horticulture (Campinas), 17(2), 167-174. http://dx.doi.org/10.14295/rbho.v17i2.713.

Balbi, R. V., Pio, R., Farias, D. H., Melo, E. T., Pereira, M. P., \& Pereira, F. J. (2019). The cell regeneration and connection of grafting between pear and quince trees are defined by the cortex and phloem. Scientia Horticulturae, 257, 108662. http://dx.doi.org/10.1016/j.scienta.2019.108662.

Barbosa Filho, J., Carvalho, M. A. D., Oliveira, L. S., Konzen, E. R., Campos, W. F., \& Brondani, G. E. (2016) Propagation of Khaya anthotheca: interspecific grafting with Swietenia macrophylla and air layering. Cerne, 22(4), 475-484. http://dx.doi.org/10.1590/01047760201622042232.

Baron, D., Esteves Amaro, A. C., Pina, A., \& Ferreira, G. (2019). An overview of grafting re-establishment in woody fruit species. Scientia Horticulturae, 243, 84-91. http://dx.doi.org/10.1016/j.scienta.2018.08.012.

Cowles, H., \& Chamberlain, C. J. (1911). Graft hybrids and chimeras. Botanical Gazette, 51(2), 147-153. http://dx.doi.org/10.1086/330463.

Darikova, J. A., Savvaa, Y. V., Vaganova, E. A., Gracheva, A. M., \& Kuznetsovab, G. V. (2011). Grafts of woody plants and the problem of incompatibility between scion and rootstock (a review). Journal of the Siberian Federal University, 1(4), 54-63. 
Facciuto, G., Soto, S., Mata, D., Hagiwara, J. C., Miyajima, I., \& Kobayashi, N. (2005). Propagation of new Tabebuia heptaphylla (lapacho) clones through grafting method: rootstock influence. Acta Horticulturae, (683), 129-132. http://dx.doi.org/10.17660/ActaHortic.2005.683.12.

Feng, J.-J., Yang, Z.-J., Chen, S.-P., El-Kassaby, Y. A., \& Chen, H. (2017). Signaling pathway in development of Camellia oleifera nurse seedling grafting union. Trees, 31(5), 1543-1558. http://dx.doi.org/10.1007/s00468-017-1568-9.

Ferrari, M. P., Grossi, F., \& Wendling, I. (2004). Propagação vegetativa de espécies florestais. Colombo: Embrapa Florestas.

Ferreira, E. B., Cavalcanti, P. P., \& Nogueira, D. A. (2018). ExpDes.pt: pacote experimental designs (portuguese). R package version 1.2.0. Vienna: R Foundation for Statistical Computing. Retrieved in 2021, April 21, from https://CRAN.R-project.org/package=ExpDes.pt

Font i Forcada, C., Gogorcena, Y., \& Moreno, M. A. (2012). Agronomical and fruit quality traits of two peach cultivars on peach-almond hybrid rootstocks growing on Mediterranean conditions. Scientia Horticulturae, 140, 157-163. http://dx.doi.org/10.1016/j.scienta.2012.04.007.

Gomes, W. A., Mendonça, R. M. N., Souza, E. P., Estrela, M. A., Melo, V. S., Silva, S. M., \& Souza, A. P. (2010). Garfagem e diâmetro de porta-enxerto na obtenção de mudas de umbuzeiro do acesso laranja. Revista Brasileira de Fruticultura, 32(3), 952-959. http://dx.doi.org/10.1590/S010029452010000300041.

Hodel, D. R., Henrich, J. E., Greby, K. J., \& Yansura, D. (2017). Handroanthus x lewisii (Bignoniaceae), a new hybrid from cultivation. Phytoneuron, 46, 1-21.

Hussain, S., Curk, F., Anjum, M. A., Pailly, O., \& Tison, G. (2013). Performance evaluation of common clementine on various citrus rootstocks. Scientia Horticulturae, 150, 278-282. http://dx.doi.org/10.1016/j.scienta.2012.11.010.

Johkan, M., Mitukuri, K., Yamasaki, S., Mori, G., \& Oda, M. (2009). Causes of defoliation and low survival rate of grafted sweet pepper plants. Scientia Horticulturae, 119(2), 103-107. http://dx.doi.org/10.1016/j.scienta.2008.07.015.

Kalil Filho, A. N., Hoffmann, H., Santana, D. D. Q., \& Tracz, A. (2008). Avaliação de combinações enxerto/porta-enxerto visando indução de resistência à broca das meliáceas por enxertia (Boletim de Pesquisa e Desenvolvimento, No. 41, 21 p.). Colombo: Embrapa Florestas.

Kumar, S., Gao, L. X., Yuan, H. W., Xu, D. B., Liang, Z., Tao, S. C., Guo, W. B., Yan, D. L., Zheng, B. S., \& Edqvist, J. (2018). Auxin enhances grafting success in Carya cathayensis (Chinese hickory). Planta, 247(3), 761-772. http://dx.doi.org/10.1007/s00425-017-2824-3.

Machado, B. D., Magro, M., Rufato, L., Bogo, A., \& Kreztschmar, A. A. (2017). Graft compatibility between european pear cultivars and East Malling "C" rootstock. Revista Brasileira de Fruticultura, 39(3), e-060. http://dx.doi.org/10.1590/0100-29452017063.

Malagi, G., Citadin, I., Scariotto, S., Wagner Júnior, A., \& Sachet, M. R. (2012). Enxertia interespecífica de jabuticabeira: influência do tipo de garfo. Ciência Rural, 42(2), 221-224. http://dx.doi.org/10.1590/S0103-84782012005000006.

Martínez-Ballesta, M. C., Alcaráz-López, C., Muries, B., Mota-Cadenas, C., \& Carvajal, M. (2010). Physiological aspects of rootstock-scion interactions. Scientia Horticulturae, 127(2), 112-118. http://dx.doi.org/10.1016/j.scienta.2010.08.002.

Mudge, K., Janick, J., Scofield, S., \& Goldschmidt, E. E. (2009) A history of grafting. In J. Janick (Ed.), Horticultural reviews (Vol. 35, pp. 437-493). Hoboken: Wiley-Blackwell. http://dx.doi.org/10.1002/9780470593776.ch9.

O'Neill, M. E., \& Mathews, K. L. (2000). A weighted least squares approach to levene test of homogeneity of variance. Australian \& New Zealand Journal of Statistics, 42(1), 81-100. http://dx.doi.org/10.1111/1467-842X.00109.

Opoku, E. M., Opuni-Frimpong, E., \& Dompreh, D. (2019). Developing sustainable regeneration techniques for four African mahogany species: grafting methods for success and growth. New Forests, 50(4), 539-554. http://dx.doi.org/10.1007/s11056-018-9677-x.

Orazem, P., Stampar, F., \& Hudina, M. (2011). Quality analysis of ‘Redhaven’ peach fruit grafted on 11 rootstocks of different genetic origin in a replant soil. Food Chemistry, 124(4), 1691-1698. http://dx.doi.org/10.1016/j.foodchem.2010.07.078.

Peil, R. M. (2003). A enxertia na produção de mudas de hortaliças. Ciência Rural, 33(6), 1169-1177. http://dx.doi.org/10.1590/S0103-84782003000600028. 
Pereira, I. S., Fachinello, J. C., Antunes, L. E. C., Campos, A. D., \& Pina, A. (2014). Incompatibilidade de enxertia de Prunus. Ciência Rural, 44(9), 1519-1526. http://dx.doi.org/10.1590/0103-8478cr20131074.

R Core Team (2021). R: a language and environment for statistical computing. Vienna: R Foundation for Statistical Computing. Retrieved in 2021, April 21, from http://www.R-project.org/

Robert, M. L., Juaréz-Gómez, J., Chaires-Pacheco, M., \& Peña-Ramírez, Y. J. (2019). Successive grafting confers juvenility traits to adult Spanish red cedar (Cedrela odorata Linnaeus): a tool for the rescue of selected materials. New Forests, 51(2), 335-347. http://dx.doi.org/10.1007/s11056-019-09736-7.

Rodrigues, A. C., Fachinello, J. C., Silva, J. B., Fortes, G. R. de L., \& Strelow, É. (2004). Compatibilidade entre diferentes combinações de cvs. copas e portaenxertos de Prunus sp. Revista Brasileira de Agrociência, 10(2), 185-189. http://dx.doi.org/10.18539/cast.v10i2.916.

Simões, I. M., Alexandre, R. S., Rosa, T. L. M., Medeiros, R. G., Schimildt, E. R., Oliveira, J. T. S., Lopes, J. C., Oliveira, J. P. B., Ferreira, A., \& Otoni, W. C. (2021). Grafting among species of the genus Handroanthus (Bignoniaceae). Scientia Forestalis. In press.

Storch-Böhm, R. F., Somensi, C. A., Cotelle, S., Deomar-Simões, M. J., Poyer-Radetski, L., Dalpiaz, F. L., Pimentel-Almeida, W., Férard, J.-F., \& Radetski, C. M. (2020). Sensitivity of different parameters for selection of higher plants in urban afforestation: exposure of guabiroba (Campomanesia xanthocarpa O. Berg.) to diesel engine exhaust. Environmental Pollution, 265, 114675. http://dx.doi.org/10.1016/j.envpol.2020.114675.

Uthup, T. K., Karumamkandathil, R., Ravindran, M., \& Saha, T. (2018). Heterografting induced DNA methylation polymorphisms in Hevea brasiliensis. Planta, 248(3), 579-589. http://dx.doi.org/10.1007/s00425-018-2918-6.

Van Ryswyk, K., Prince, N., Ahmed, M., Brisson, E., Miller, J. D., \& Villeneuve, P. J. (2019). Does urban vegetation reduce temperature and air pollution concentrations? Findings from an environmental monitoring study of the Central Experimental Farm in Ottawa, Canada. Atmospheric Environment, 218, 116886. http://dx.doi.org/10.1016/j.atmosenv.2019.116886.

Authors' contributions: IMS: Conceptualization, data curation, investigation, methodology, project administration, validation, visualization, writing - original draft. JCL: Investigation, writing - review \& editing; ERS and AF: Formal analysis, writing - review \& editing; JOB, CPA, TLMR: Investigation, writing - review \& editing; GCA: Writing - review \& editing; RSA: Conceptualization, data curation, funding acquisition - investigation, methodology, project administration, resources, supervision, validation, visualization, writing - original draft. 